
КУЛЬТУРА ПРОФЕСІЙНОЇ САМОРЕАЛІЗАЦІЇ ВЧИТЕЛЯ
ЯК НАУКОВА ПРОБЛЕМА ПЕДАГОГІКИ ВИЩОЇ ШКОЛИ

\title{
CULTURE OF TEACHER'S PROFESSIONAL SELF-REALIZATION AS A SCIENTIFIC PROBLEM OF HIGH SCHOOL PEDAGOGY
}

У статті розглянуто низку питань щодо витоків проблеми культури профресійно самореалізації сучасного вчителя, яка обумовлена об'єктивними вимогами і очікуваннями соціуму щодо етичних, правових моральних норм, академічної доброчесності та вимог сучасного суспільства до якості освіти. Подано засновану на висновках педагогів-науковців коротку загальнонаукову характеристику педагогічної культури, яка передбачає високу усвідомленість вчителем свого покликання, міри особистісного самопізнання, манери спілкування у просресійній діяльності та має тісний зв'язок із загальнокультурними і моральними проявами особисмості педагога.

Автор звертає увагу на те, що найбільшої професійної та особистісної успішності домагається людина, здатна до повноцінної творчої самореалізації в значущій для неї і важливій для суспільства діяльності. Актуалізується проблема навчання та виховання підростаючих поколінь громадян, яке буде здійснюватися педагогами, самореалізованими у профресійній діяльності. Наголошується, що професійна діяльність сучасного вчителя має здійснюватися в умовах широкого вибору підходів до організації прочесу навчання, а тому в сучасних умовах освітніх ресрорм особливо гостро виникає необхідність формування готовності вчителів до культури самореалізації у професійній діяльHOCmi.

Під самореалізачією особистості майбутнього вчителя розуміється процес, спрямований на усвідомлення, виявлення і прояв своїх індивідуальних і професійних можливостей, здійснення планів, які забезпечують досягнення найвищих результатів у навчально-професійної діяльності та затвердження себе не тільки як особистості, а й як професіонала.

Однак поки що не достатньо розроблений єдиний ефективний механізм науково-методичного супроводу та аналізу інформації щодо профресійного становлення спеціаліста, визначення культури його профресійної самореалізації з урахуванням динаміки цих процесів на рівні адміністративно-методичних і управлінських служб. Особливості процесу та змісту культурної самореалізації вчителя, створення умов для його профресійної самореалізації в організаціях різних типів (дошкільної, загальної, спеціальної освіти, державних і приватних закладах тощо) постає одним зі стратегічних напрямів державної політики України в ссрері просресійної педагогічної освіти. Вирішення означеної педагогічної проблеми дозволить на практииі створювати умови, які сприятимуть становленню і розвитку у майбутніх педагогів внутрішніх передумов, що забезпечать есективність їх культурної профресійно самореалізації.

Ключові слова: просесійна культура, професійна самореалізація, професійно-особис- тісний розвиток вчителя, педагогіка вищої школи.

The article considers a number of issues regarding the origins of the culture problem of the profes sional self-realization of a modern teacher, which is conditioned by the objective demands and expectations of the society concerning moral standards, academic integrity and the requirements of modern society to the quality of education. A brief general scientific description of the pedagogical culture based on the conclusions of educators and scientists is given, which implies a teacher's high awareness of his calling, measures of personal self-knowledge, manner of communication in professional activity and has a close relationship with the general cultural and moral manifestations of the personality of the teacher.

Self-realization of the personality of a future teacher is implied as a process aimed at understanding, identifying and manifesting one's individual and professional abilities, implementing plans to achieve high results in educational and professional activities and establishing oneself not only as an individual, but also as a professional.

The author draws attention to the fact that the greatest professional and personal success is achieved by a person who is capable of full cre ative self-realization in activities that are significant for him and important for society. The problem of training and upbringing of the younger generations of citizens, which will be carried out by educators, is self-actualizing in professional activity. It is noted that the professional activity of a modern teacher should be carried out in the context of a wide choice of approaches to the organization of the learning process, and therefore, in the current conditions of educational reforms, the need for the formation of teachers readiness for a culture of self-realization in professional activity is especially important.

At the same time, a unified effective mechanism for scientific and methodological support and analysis of information on the professional development of a specialist, determination of the culture of his professional self-realization, taking into account the dynamics of these processes at the level of administrative, methodological and managerial services, is not yet sufficiently developed. Features of the process and content of the teacher's cultural self-fulfillment, creation of conditions for his professional self-realization in organizations of various types (preschool, general, special education, public and private institutions, etc.) is one of the strategic directions of the state policy of Ukraine in the field of professiona pedagogical education. The solution of the indicated pedagogical problem will make it possible in practice to create conditions enabling to the formation and development of future background for future teachers to ensure the effectiveness of their cultural professional self-realization. Key words: professional culture, professional self-realization, professional and personal development of a teacher, high school pedagogy. 
Постановка проблеми в загальному вигляді. Гуманістична спрямованість сучасної вищої освіти в Україні змінює багаторічне традиційне уявлення щодо їі мети як фрормування «систематизованих знань, умінь і навичок». Натепер важливим завданням є забезпечення особистісного та професійного зростання здобувачів освіти, формування необхідних у професійній діяльності компетентностей і надання їм широкого спектру можливостей для самореалізації в профресійній сорері. Особливості процесу та змісту культурної самореалізації вчителя, створення умов для його профресійної самореалізації в організаціях різних типів (дошкільної, загальної, спеціальної освіти, державних і приватних закладах тощо) постає одним зі стратегічних напрямів державної політики України у сорері освіти [4].

Спершу автор розглядає проблему фрормування культури сучасного вчителя, яка постає в світлі освіченості особистості, що виражається в якості його розвиненої здатності до самодослідження і самовдосконалення, вимірі внутрішнього потенціалу та власних сил, фрормуванні і вихованні моральних якостей. Все перераховане впливає на майбутнє педагога, на пошук ним свого місця в житті, можливість всебічно розвиватися, самостверджуватися в суспільстві та самореалізовуватися в обраній профресії.

Аналіз останніх досліджень і публікацій. Аналізуючи літературні джерела в рамках означеної проблематики, автор звертає увагу на розвідки І. Зязюна, О. Леонтьєва, Н. Сегеди, Н. Стрельникової та інших, де важливим $є$ розвиток професійнопедагогічної підготовки вчителя та його здатності до професійної самореалізації. Проблему професійної культури педагога досліджували О. Гармаш, В. Гриньова, О. Растригіна, О. Рудницька, Т. Сидоренко, С. Чорна та інші.

Виділення не вирішених раніше частин загальної проблеми. Аналіз наукової літератури свідчить, що ця проблема методологічно пов'язана з розумінням особистості як творця свого життєвого шляху (С. Рубінштейн, Б. Ананьєв, А. Брушлинський). Натепер важливим завданням є забезпечення особистісного та професійного зростання здобувачів освіти, формування необхідних компетентностей і надання їм широкого спектру можливостей для самоздійснення в профресійній сорері життєдіяльності.

Мета статті. Мета статті полягає в фрормуванні культури профресійної самореалізації вчителя як педагогічної проблеми, у висвітленні значення культури як особистісної якості педагога, пошуку ії місця у професійній самореалізації і становленні вчителя та актуалізації означеної проблеми для освітньої системи вищої школи.

Виклад основного матеріалу. Відомим фрактом $€$ той, що людина проявляє свої здібності в усіх сорерах життєдіяльності: у суспільстві і сім'ї, в сорері власних інтересів, захоплень, у сорері профресійної діяльності. Однак найбільш повне розкриття внутрішніх сил людини можливе лише в суспільно значимій діяльності, різні види якої системно представлені в різних профресіях. Саме так Л. Виготський фрормулює гіпотезу про інтеріоризацію соціальних фрорм діяльності в індивідуальні, підкреслюючи, що в процесі культурного розвитку «через інших ми стаємо самими собою, і це правило стосується не тільки конкретної особистості, але й історії кожної окремої нації» [1, с. 144-146].

Тлумачення поняття «культури» $є$ дуже багатозначним. Існують десятки, якщо не сотні таких визначень. Культура в широкому сенсі складається зі знань, вірувань, мистецтва, моральності, законів, звичаїв і деяких інших здібностей і звичок, засвоєних людиною як членом суспільства. Серед найвідоміших науковців, які займаються дослідженням цієї проблеми, слід назвати вітчизняних вчених Є.С. Аверінцева, Є.С. Маркаряна, А.С. Гуревича, Л.С. Кертмана, М.С. Кагана, В.М. Межуєва, Ю.М. Рєзніка [11, с. 22].

Особливого значення набуває пошук змісту френомена формування культури. Зважаючи на означене, можна передбачити той фракт, що педагогічна культура вчителя є частиною загальнолюдської культури, у якій об'єднуються духовні цінності освіти і виховання (педагогічні знання, теорії, концепції, накопичений педагогічний досвід, профресійні етичні норми) та матеріальні (засоби навчання і виховання), а також способи творчої педагогічної діяльності, які слугують ефективним підґрунтям для соціалізації особистості.

Педагогічна культура вчителя $€$ системним утворенням, яке включає педагогічні цінності, творчі способи педагогічної діяльності, досвід створення учителем зразків педагогічної практики тощо. Показниками високого рівня сорормованості педагогічної культури слід вважати:

1) гуманістичну спрямованість особистості педагога;

2) психолого-педагогічну компетентність і розвинуте педагогічне

мислення;

3) освіченість у галузі предмета, який вчитель викладає, і оволодіння

педагогічними технологіями;

4) досвід творчої діяльності, вміння обґрунтовувати власну педагогічну

діяльність як систему (дидактичну, виховну, методичну);

5) культуру профресійної поведінки (педагогічного спілкування, мови,

зовнішнього вигляду) [9].

Згідно з наведеною настановою культура вчителя і педагогічна культура, синонімізована з нею, характеризують процес засвоєння соціальних 
цінностей, стан особистості, а також процес створення у процесі педагогічної діяльності нових соціальних цінностей. Наукове розроблення поняття педагогічної культури майбутніх учителів, проблематизоване навколо розглянутого концепту «культура», інтенсифікувалося в останні роки. Важливо, щоб здійснення цієї діяльності домінувалося не лише ззовні (суспільством), але і внутрішньою потребою особистості. Діяльність особистості в цьому випадку стає самодіяльністю, а реалізація її здібностей у такій діяльності здобуває характер самореалізації [2, с. 410].

Визначенню самореалізації як вродженої якості людини імпонують погляди американського психолога К. Роджерса. Цей френомен він визначає в якості основного мотиву особистісного зростання людини, наголошуючи, що до самореалізації здатна лише та особа, у якої актуалізована самість. «Я-концепція», або «Самість» - фрундаментальне поняття теорії К. Роджерса, яке визначається як гештальт, що складається з сприйняття себе і своїх взаємин 3 іншими людьми, а також із цінностей «Я». Складниками «я-концепції» $€$ «я - реальне» і уявлення про себе таким, яким би людина хотіла бути («Я -ідеальне») [7]. Основоположним в усіх працях К. Роджерса $€$ твердження про те, що людина, спостерігаючи і оцінюючи свій власний досвід, пізнає саму себе. При цьому протягом всього життєвого шляху вона відчуває потребу в реалізації свого потенціалу.

При розгляді категорії самореалізації можна виділити два аспекти: внутрішній - особистісний, за яким самореалізація розглядається як стан, мета або результат, чого можна досягти в ході особистісного зростання і розвитку людини як суб'єкта власного життя, і зовнішній - діяльнісний, коли самореалізація розглядається як процес або засіб досягнення життєвого успіху, в тому числі і в профресійній сорері [9, 10].

Цікавою є думка Л. Рибалко, яка наголошує, що впровадження акмеологічних ідей розвитку та саморозвитку особистості педагога, фрормування професійної «Я»-концепції вчителя, досягнення акме через профресіоналізм і педагогічну майстерність сприяють підвищенню ефрективності педагогічного процесу, зростанню педагогічної культури педагога, гарній побудові міжособистісних відносин на засадах співпраці, ефективній самореалізації в умовах профресійної діяльності [6].

Профресійна самореалізація має стати метою педагога, самоактуалізацією його особистості, професійних якостей, загальної особистісної культури. Його досягнення у професійній діяльності мають стати метацінністю. Самореалізація вчителя як особистісний стан розглядається в низці досліджень [3, 7, 10] як задоволеність самореалізацією. В цьому аспекті самореалізація в якості результату частіше досліджується вченими як певний рівень особистісного розвитку за критерієм «успіх - неуспіх». Результатом самореалізації може стати наявність професійних властивостей, які сприяють самоздійсненню особистості.

Під самореалізацією особистості майбутнього вчителя автор розглядає процес, спрямований на усвідомлення, виявлення і прояв своїх індивідуальних і професійних можливостей, здійснення планів, які забезпечують досягнення найвищих результатів у навчально-професійній діяльності та затвердження себе не тільки як особистості, але і як профресіонала. Самореалізація особистості в психолого-педагогічній інтерпретації пов'язується 3 зовнішнім і внутрішнім фракторами. Інакше кажучи, вона не відбувається «сама собою», а тому для процесу її здійснення потрібно забезпечити необхідні умови для самоактуалізації особистості.

За А. Маслоу, самоактуалізація - це процес, який дає змогу людині стати тим, ким вона може стати, але він обмежується цим, зовсім не звертаючи увагу на психологію того, хто самореалізується [3, с. 304]. Спрямованість освіти змінює вектор вітчизняної освіти із фрормування «систематизованих знань, умінь і навичок» на забезпечення можливостей для особистісного, профеесійного зростання та для здійснення самореалізації вчителя у професійній діяльності.

Предметом наукового інтересу у фрундаментальній праці Н. Сегеди є професійний розвиток викладача музичного мистецтва, в якому дослідниця ґрунтовно описує професійну самореалізацію вчителя музичного мистецтва, наголошуючи на важливості особистісного компоненту, який вбачає у цілісності особистості, її потенціалі та індивідуально-профресійному ресурсі вчителя як засобу і результаті професійного зростання педагога. Науковець робить висновки про те, що виявами істинного суб'єкта професійного зростання $€$ вільний вибір, саморозвиток професійно-педагогічної якості, який здійснюється поза утилітарними потребами (фрізичний стан, мислення, досвід, здібності, самість, емоції) як френомени ситуативно не стимульованої діяльності, спрямованої на перетворення творчого потенціалу особистості в індивідуально-професійний ресурс. Така специфрічна самотворчості у сфері профресійної діяльності не є запрограмованою генетичною індивідуальною властивістю [8, с. 166].

На основі означеного можна сказати, що профресійна самореалізація педагога, набуття ним культури для здійснення викладацької діяльності $€$ безперервним особистісним процесом самопізнання і саморозвитку. Для майбутнього педагога такою можливістю стає навчання у ВН3, де окрім набуття теоретичних знань він може оволодіти практичними уміннями і набути фрахових компетентностей. Важливою в цьому аспекті 
$€$ педагогічна практика, яка в системі профресійної підготовки майбутнього вчителя є можливістю для самовизначення у професії і набуття необхідних якостей для фрормування культури профресійної самореалізації.

Педагогічна практика є видом практичної діяльності студентів, специфіка якої полягає в тому, що саме в ній здебільшого можна спостерігати ідентифрікацію з профресійною діяльністю. Вона є сполучною ланкою між теоретичним навчанням майбутніх вчителів і їх самостійною роботою в установах освіти. Практика - це перш за все процес оволодіння різними видами професійної діяльності, в якому навмисно створюються умови для самопізнання та самовизначення студента в різних професійних ролях, де фрормується потреба в самовдосконаленні та самореалізації.

Період практики є якісно новим щаблем в освітньому процесі, який сприяє особистісно-профресійному розвитку студента, найважливішим «інструментом» діяльності стає особистісна позиція студента, зміст і засоби педагогічної діяльності, обрані ним під час педагогічної практики. Найважливішою особливістю практики є їі спрямованість на особистісно-професійний розвиток, тобто на самореалізацію особистості майбутнього вчителя.

Більшість дослідників професійної самореалізації, в тому числі і самореалізації вчителя, зазначають у своїх роботах, що самореалізація конкретної людини може входити в суперечність 3 інтересами соціальної групи. Кожен культурний регіон, де проживають люди різних національностей, має свою виховну специфіку. Феномен культури загалом визначається як історично обумовлений рівень розвитку суспільства, творчих сил і здібностей людини, виражений у типах організації життя і діяльності людини, що сприяє успішності самореалізації.

Висновки. Актуалізація уваги до проблеми самореалізації особистості в сучасній науці і освітній практиці ВНЗ пояснюється важливістю проблеми, пов'язаної 3 дослідженням суб'єктної активності особистості, максимального використання внутрішніх ресурсів для повного самоздійснення майбутнього вчителя в процесі його становлення та соціалізації.

Профресійну самореалізацію вчителя розглянуто як педагогічну проблему, сутність якої полягає в постійному самовдосконаленні й саморозвитку власного потенціалу. Самореалізація вчителя $\epsilon$ необхідною умовою для розвитку як окремої особистості, так і поступального розвитку суспільства.
Культура професійної самореалізації вчителя в психологічному аспекті має неоднозначне трактування, однак ключовим є поняття сутнісних сил людини, які проявляються і розвиваються в особистісних і суспільно значимих діях (у нашому випадку у профресійній діяльності). Самореалізація $€$ реалізацією (проявом) існуючого внутрішнього потенціалу, здійсненням своїх прагнень, знань, умінь і здібностей відповідно до особистісних уявлень про себе і свій шлях у житті. Вона впливає на вибір профресії і стає важливим складником фрормування особистісної культури педагога.

Теоретичний аналіз проблеми культури професійної самореалізації вчителя дає підстави говорити, що для її вирішення необхідна наукова актуалізація цього питання у співвідношенні внутрішніх індивідуальних установок особистості вчителя і зовнішніх умов, які перешкоджають або навпаки сприяють ії̈ самореалізації у просресії. Це і стане подальшим вектором дослідження автора.

\section{БІБЛІОГРАФІЧНИЙ СПИСОК:}

1. Выготский Л.С. Педагогическая психология. Москва : Педагогика-Пресс. 1996. 536 с.

2. Зязюн І.А. Педагогічна майстерністьт : підручник для вищих навч. закл. Київ : «Вища школа». 2004. $422 \mathrm{c}$.

3. Маслоу А. Психология бытия. Москва : Ваклер. 1997. 304 c.

4. Нормативно-правові документи галузі освіта URL: http://zakon3.rada.gov.ua (дата звернення: 20.01.2020).

5. Пономарьов О.С. Культура профресійної діяльності в системі категорій педагогіки вищої школи. Теорія і практика управління соціальними системами. Щоквартальний науково-практичний журнал. Харків : НТУ «ХП|». 2012. № 4. с. 128.

6. Рибалко Л.С. Методолого-теоретичні засади профресійно-педагогічної самореалізації майбутнього вчителя (акмеологічний аспект) : монографрія. Запоріжжя : ЗДМУ. 2007. 442 с.

7. Роджерс К. Становление человека. Москва : Прогресс Универс. 1994. 478 с.

8. Сегеда Н.А. Професійний розвиток викладача музичного мистецтва: історія, методологія, теорія : монографія / М-во освіти і науки України, Нац. пед. ун-т ім. М.П. Драгоманова. Київ, 2012. 273 с.

9. Туркот Т.І. Педагогіка вищої школи : навч. посіб. Київ : Кондор. 2011. 628 с.

10. Фіцула М.М. Педагогіка вищої школи : навч. посіб. Київ : Академвидав. 2006. 352 с.

11. Каган М.С. Философия культуры // Каган М.С. Избр. тр.: в 7 т. СПб., 2007. Т. 3. Труды по проблемам теории культуры. с. 22. 